\title{
Sickle Cell Chronic Lung Disease
}

National Cancer Institute

\section{Source}

National Cancer Institute. Sickle Cell Chronic Lung Disease. NCI Thesaurus. Code C155312.

A pulmonary complication of sickle cell disease characterized by radiog raphic interstitial abnormalities and impaired pulmonary function. In severe cases, pulmonary hypertension is present. 